Selcuk Koyluoglu,

Selcuk University, Turkey

(iD) ORCID ID, 0000-0003-0359-1443

email: selcuk641@gmail.com

Mesut Dogan,

Afyon Kocatepe University, Turkey

(D) ORCID ID, 0000-0001-6789-1361

email: mesutdogan07@gmail.com

Correspondence author: selcuk641@gmail.com

\title{
THE IMPACT OF INNOVATION STRATEGIES ON BUSINESS PERFORMANCE: PRACTICES IN HIGH TECHNOLOGY COMPANIES IN TURKEY
}

Abstract. Innovation efforts aim to attain important competitiveness by improving performance criteria. It has led to very strong ties between innovation and performance, which is also accepted by the recent business understanding. The purpose of the current study, which is designed in compliance with this understanding, is to examine the effect of innovation strategies on business performance in enterprises using high technology. Innovation strategies consist of 6 dimensions: proactive strategy, risk-oriented strategy, defensive strategy, future-oriented strategy, offensive strategy, and analytical strategy. Business performance was measured as product performance, employee-based performance, customer-based performance, financial performance, and process performance. The study involved the innovation strategies and business performance scale developed by Morgan and Strong (1998), Chandy and Tellis (1998), and Eskici (2020). The current study conducted a survey on 346 managers of companies operating in Turkey and using high technology. The obtained data were analyzed with the help of JAMOVI and SPSS 26.0 programs. Exploratory factor analysis, confirmatory factor analysis, Pearson correlation, and regression analysis methods were used in empirical analysis. The result determined that innovation strategies are effective on business performance. In other words, future-oriented strategy is effective on the product, customer-based, employee-based, financial, and process performances of enterprises. On the other hand, it was determined that future-oriented strategy and riskoriented strategy are not effective on enterprises' product, customer-based, employee-based, financial, and process performances. In addition, offensive, analytical, defensive, proactive, and risk-oriented strategies are ineffective in process performance. Analytical, defensive, future-oriented, and proactive strategies are effective on product performance, customer-based performance, and financial performance of businesses. As a result, it was determined that innovation strategies affect customer-based performance $(R 2=0.687)$ and financial performance $(R 2=0.701)$ of companies more.

Keywords: innovation, innovation strategies, business performance, high technology.

Introduction. Marketing products and processes by integrating them with scientific evolutions and the desire to provide commercial returns by taking serious risks have made innovation indispensable in increasing business performance. Businesses that have to keep up with the change to survive in the globalizing commercial life should care about innovation. It has become a must for businesses (Steele and Murray, 2004) since globalization has made innovation an effective weapon for businesses to expand their market penetration with new products (Liao and Rice, 2010). The goal of innovation efforts is to achieve competitiveness by improving performance criteria (Tomlinson, 2010). It has led to very strong ties between innovation and performance, which is also accepted by the recent business understanding. Therefore, innovation, which is considered to be an activity that fosters business performance (Kaplan and Norton, 1996), is a critical factor that has a significant impact on both the success and sustainability of the firm and industry (Cozzarin, 2006; Brown and Maylor, 2005).

Cite as: Koyluoglu, S., \& Dogan. M. (2021). The Impact of Innovation Strategies on Business Performance: Practices in High Technology Companies in Turkey. Marketing and Management of Innovations, 4, 168183. http://doi.org/10.21272/mmi.2021.4-13 
According to Kuczmarski (1996), to have a real competitive opportunity with innovation, it is essential to make customers perceive it as an innovation. Cottam et al. (2001) underlined that high performance depends on the number of innovative applications. On the other hand, the results could be negative for businesses from time to time, as innovative applications also contain some risks. If risks such as competition risk and change risk could not be managed properly in the innovation process, the result could be disappointing. In this respect, innovation is not just about surviving or making the existence sustainable for firms. It could also result in the extinction of the firm due to wrong policies (Meeus and Oerlamans, 2000). In this connection, Prajogo and Sohal (2001) established a linear relationship between product innovation and the firm's risk. They claim that the newer the product is, the higher the risk will be. For this reason, innovative businesses that could prevent the disappointment caused by the result by predicting the risks in question with effective innovation management should have certain characteristics. Innovative businesses should have the characteristics such as customer-oriented product development process and continuous customer satisfaction (Lee-Mortimer, 1995), promotion of innovation by the system and employees, considering the balance in innovation and strategic perspective in innovative products (Kuczmarski, 1996), marketing, consumer needs and post-sale services and finally, a constructive approach to innovative opinions.

This information indicates that innovation is a competitive strategy for businesses because traditional methods such as price flexibility alone are not sufficient for today's modern businesses that want to expand their market share and make their existence long-term. It has become more valuable to be able to provide satisfactory responses to today's consumers whose needs are changing and developing rapidly (Aghion et al., 2005). This necessity, which gives innovation a strategic identity, has given birth to the innovation strategy concept. Studies have also shown that businesses with such a strategy in innovation are more successful (O'Regan et al., 2005). Thus, innovation strategy could be regarded as a guide or a compass for businesses (Lendel and Varmus, 2011). Innovation strategies, which are included as sub-strategies in business strategies, have been discussed with different dimensions in the literature (Ansoff and Stewart, 1967; Venkatraman, 1989). They would be discussed more extensively in the literature review section. For the current study, 6 dimensions of Venkatraman (1989) were used. These dimensions are proactive, risk-oriented, defensive, future-oriented, offensive, and analytical strategies.

Performance usually refers to financial parameters such as profitability, market share, and growth rate (Osman et al., 2016). However, businesses that want to survive in the competition should also consider non-financial indicators such as employee performance, job satisfaction, learning, and quality (Abdalkrim, 2013). In this respect, different dimensions have been used in the literature regarding business performance measurement (Venkatraman and Ramanujam, 1986; Dess and Robinson, 1984; Hultink and Robben, 1995). Besides these dimensions, some models have also been designed. Performance Measurement Matrix, Performance Pyramid System, Balanced Scorecard, Integrated Performance Measurement System, Performance Prism, and Organizational Performance Measurement are among these models (Garengo et al., 2005). The balanced scorecard model (Kaplan and Norton, 1996; Kaplan, R. S., 1998) was used in the current study. In this model, the researchers used financial, customer, internal business processes, and learning and growth performances in their sub-dimensions as business performance indicators.

High technology is an important pillar of the subject of the study. It is used in the sense of the most advanced technology and expresses the change that occurs over time. Notably, high technology describes technologies in the present rather than in the past or future. Therefore, high technology products of the 1960s have become standard today. Moreover, they could be considered low-tech products. Nowadays, the number of sectors considered high technology has increased according to the technology intensity used compared to 20-30 years ago (Audretsch and Acs, 1991). High technology users are energy, telecommunication, chemistry, and computer sectors. On the other hand, low technology does not require 
intensive technology in companies' production processes or service production. In turn, the investment cost is less than the sectors using high technology. Industries such as textiles, food, or cement are considered low-tech (Covin et al., 2000).

The current study was designed to determine the effect of companies' innovation strategies using high technology on their business performance. In Turkey, innovation strategies and product, financial, process, employee, and customer-based performance levels of companies using high technology have been investigated. Thus, high-tech companies where innovation is much more important were selected for the current study. The number of studies examining the effect of innovation strategies of businesses using high technology on business performance is not considered to be sufficient. Therefore, in the current study, business performance was evaluated in 5 different dimensions as follows: financial, product, process, employee, and customer-based performance. Thus, it differs from other studies in the literature. In this context, this paper contributes to the literature. In the study, the innovation strategies and business performance scales developed by Morgan and Strong (1998), Chandy and Tellis (1998), Eskici (2020) were used. In this connection, a questionnaire was administered to 346 managers of companies using high technology in Turkey. The collected data were analyzed by using JAMOVI and SPSS 26.0 programs. Exploratory factor analysis, confirmatory factor analysis, Pearson correlation, and regression analysis methods were used in the empirical analysis.

The study continues with section 2, presenting a review of the literature. Section 2 presents a literature review on innovation strategy and its sub-dimensions, business performance, and the relationship between innovation strategies and business performance. Then, section 3 provides the study's purpose, significance, and methodology. Section 4 is the section where empirical results derived from the analyses are reported. Finally, section 5 is the section where discussion, limitations, and future research proposals are presented.

Literature Review. Many definitions of innovation have been made in the literature (Damanpour, 1991; Karlsson and Olsson, 1998; Jenssen and Jorgensen, 2004; Li et al., 2013). These definitions show that there is no generally accepted definition of the concept of innovation. However, it can be said that the definitions revolve around three main approaches: (1) the approach that sees innovation as the economic effect of technological change (Pichler, 2010); (2) the approach that sees innovation as a means of combining science, technology, economics, and management, (3) the approach that sees innovation as new knowledge (Afuah, 1998). Based on these approaches, innovation alone refers only to the process. However, the success of innovation depends on business processes such as customers, suppliers, and external resources and the ability to manage technology and human relations well. It is possible by having a strategic innovation perspective. Therefore, the functions of effective innovation management are customers, suppliers, technology, organizational structure, innovation culture, and innovation strategies (Maggitti et al., 2013). This study explains the innovation strategies among these functions.

It is possible to reach various definitions of innovation strategies (Lendel and Varmus, 2011; Gilbert, 1994; Oke et al., 2012; Manu and Sriram, 1996; Zhuang, 1995). However, the definition made by Cerami (2001) is more inclusive than the others. According to him, an organization with innovative strategies should take a proactive attitude. At the same time, it should research new sustainable opportunities, monitor competitor activities, and invest more in R\&D (Oke et al., 2012). The firm should consider various factors while pursuing its innovation strategies. The market structure, technological features, legal procedures, technological power, financial power, and bargaining power of the firm against other firms could be listed among these factors (Kim et al., 1999). Since innovation strategies that see it important to consider these factors have a special value in terms of catching a company's synchronized harmony with its environment, the number of studies on the subject in the literature is quite high (Ansoff and Stewart, 1967; Venkatraman, 1989; Manu and Sriram, 1996; Lambkin, 1988). In these studies, innovation strategies were subjected to different classifications and discussed with their different dimensions. 
Lambkin (1988) analyzed innovation strategies by dividing them into cost reducers, fast replicators, and technological innovators. New technology is developed to improve the performance of a product. It is followed by the replicators who are constantly monitoring the market, and when the rate of change of the market decreases, cost reducers come into play. Wright et al. (1990) adopted a collective attitude towards the issue of strategy for firms to increase their performance levels further. They added the balanced strategy, a new one, to the reactive, analytical, innovative, and defensive strategies. In their study, Lynn and Mazzuca (1998) divided innovation strategies into the customer, process, learning, and leading directive groups. They emphasized the concepts of market orientation and customer-centric. Veugelers and Cassiman (1999) divided innovation strategies into two groups. These are the innovations produced by the firm and the strategies that the firm buys from outside. The goal that companies want to achieve with these strategies is to integrate into innovation. Johne and Snelson (1988) approached innovation strategies from two perspectives: classical and market-oriented. While the main objectives adopted in the classical understanding are to reduce costs and improve the product line, opening outside is the main objective adopted in the market-oriented approach. Cooper (1984) characterized innovation strategies in five different ways and concluded that the strategy adopted by the firm affects its innovation performance. Venkatraman (1989), on the other hand, addressed innovation strategies in 6 dimensions: proactive, riskoriented, defensive, future-oriented, offensive, and analytical strategies.

The general conviction in the literature is that innovation strategies have a positive effect on firm performance (Wu and Lin, 2011). The current study considers the paper by Venkatraman (1989) as the basis for creating hypotheses and innovation strategies discussed in their 6 dimensions. The effect of innovation strategies on firm performance constitutes the main hypothesis. The other hypotheses are the sub-dimensions of this hypothesis. The main hypothesis is given below:

$\mathrm{H} 1$ : There is a significant relationship between innovation strategies and firm performance.

In this connection, the first of the sub-dimensions is an offensive strategy. This strategy, as the name suggests, represents a tough attitude. This tough attitude characterizes the firm's attitude in the market. It is the attitude adopted by the business at the point of resource reserve to move its position in the market further (Venkatraman, 1989). This strategy seeks an intense competitive trend in businesses. In this way, an effective response to the activities of competitors could be given (Lyon et al., 2000). In addition, the company gains many advantages, such as increasing profitability and having projects with high returns. However, since it is a strategy that requires high investments in new products, there are some risks such as high costs, loss of time and money due to mistakes. However, successful businesses develop new products and launch them into the market by identifying customer needs faster than their competitors (Morgan and Strong, 1998). Since offensive strategy is so effective on business performance, the first subhypothesis was developed as follows:

H1a: There is a significant relationship between the offensive strategies of businesses and their business performance.

The second dimension is analytical strategy. The analytical strategy has an important place among innovation strategies because decision-making influences the organizational structure. This strategy, which is of critical importance in ensuring the adaptation of the business to the external environment, is a factor that should be possessed to have innovative advantages (Miller and Friesen, 1984). The second sub-hypothesis for this strategic dimension, which paves the way for the implementation of risk-taking and pro-activity strategies, is as follows:

$\mathrm{H} 1 \mathrm{~b}$ : There is a significant relationship between the analytical strategies of businesses and their business performance.

The third strategic dimension is the defensive strategy. Businesses that adopt this strategy exhibit a far from proactive behavior (Morgan and Strong, 1998). They aim to maintain the current market situation, but they do not want to risk being first on the market. Thus, their adaptability is limited. In other words, to 
maintain their customer portfolio in the market, they try to make small changes in existing products rather than coming up with new products. Therefore, they continue their activities in a secure position, almost completely free from uncertainty (Mavondo, 2000). The third sub-hypothesis for the defensive dimension, which focuses on high-quality-low-price practice within innovation strategies, is formed as follows:

$\mathrm{H} 1 \mathrm{c}$ : There is a significant relationship between the defensive strategies of businesses and their business performance.

The future-oriented strategic dimension is the fourth sub-dimension of innovation strategies. The future-oriented strategic dimension is a dimension that explains, in order of importance, the factors that should be considered in sometimes medium but mostly long-term strategic maneuvers of the business. Efficiency and effectiveness are among these factors (Venkatraman, 1989). Many researchers stated that focusing on the future has several advantages. These advantages could be listed as taking advantage of innovation opportunities by anticipating needs (Kandampully and Duddy, 1999), transforming creative ideas into innovative products (Kohli and Jaworski, 1990), and assisting the long-term plans of the enterprise (Chandy and Tellis, 1998). In line with these explanations, the fourth sub-hypothesis for the effect of the future-oriented strategic dimension on business performance is defined as follows:

$\mathrm{H} 1 \mathrm{~d}$ : There is a significant relationship between the future-oriented strategies of businesses and their business performance.

Another sub-dimension is the proactive strategy. A company that has the proactive strategy is the company that is followed, not a follower because it constantly pursues innovation with a futuristic perspective (Lyon et al., 2000). Under this perspective, proactiveness could also be called a transformation ability. It leads the sector by taking the initiative (Venkatraman, 1989). The main element of proactive strategy, which considers it necessary to have an effective R\&D capability, is innovation. In this way, companies gain a competitive advantage over their competitors (Gilbert, 1994). In light of these explanations, the fifth sub-hypothesis is worded as follows:

$\mathrm{H} 1 \mathrm{e}$ : There is a significant relationship between the proactive strategies of businesses and their business performance.

The last strategic sub-dimension is risk-orientedness. Risk is essential to successful businesses, something far beyond the necessity for success $(\mathrm{Ho}, 1996)$. This dimension has a guiding role in decisions vital for the business, such as product, market, resource. Therefore, this dimension shows how much the company could bear the negative consequences of these decisions (Venkatraman, 1989). Forrester (2000) underlines that companies that take high risks for owning innovative products have a more competitive advantage. Akman and Yılmaz (2008) argued that risk-oriented strategy positively affects innovation. In this context, the last sub-hypothesis is as follows:

$\mathrm{H} 1 \mathrm{f}$ : There is a significant relationship between the risk-oriented strategies of businesses and their business performance.

Innovation, which is a driving force for the development and performance of businesses, is accepted as the key to success in competition among companies (Brown and Maylor, 2005). On the other hand, the performance makes it possible for the business to compare itself with other businesses. There is a relationship between innovation and business performance that could not be ignored because of the positive effects of innovation on business performance (Kaplan and Norton, 1996).

This tight link between the two concepts requires talking about business performance. The performance of the business could be measured objectively and/or subjectively with quantitative and qualitative data such as profitability, ROI, ROA, earnings, earnings per share, growth, market share, marketing effectiveness, new product, product quality (Veliu and Manxhari, 2017). Objective values are measured through quantitative data, while subjective values are measured with the help of qualitative data. These are also called financial and non-financial indicators (Venkatraman and Ramanujam, 1986). Although it is more common to use financial indicators to measure business performance, there are also 
arguments claiming that it is more useful to use non-financial parameters (Dess and Robinson, 1984). This different perspective has led to the introduction of various dimensions and models for measuring business performance (Venkatraman and Ramanujam, 1986; Dess and Robinson, 1984; Hultink and Robben, 1995). Performance measurement matrix, performance pyramid system, balanced scorecard, integrated performance measurement system, performance prism, and organizational Performance measurement are the models used to measure business performance (Garengo et al., 2005). The balanced scorecard model (Kaplan and Norton, 1996; Kaplan, 1998) was used in the current study. In short, the balanced scorecard is a system that pioneers constructive regulations, financial and nonfinancial indicators (Souissi and Itoh, 2006). It consists of four dimensions: financial, customer, internal processes, learning, and development. The financial dimension focuses on the business's financial goals with various strategies for it to be successful. In the customer dimension, the business determines its decisions about its goals according to the customers. Making customer satisfaction sustainable ensures the development of internal business processes. The learning and development dimension identifies strategic and structural factors and internal business and customer processes to improve the business's long-term growth (Karabulut, 2015). The integration of these dimensions with the enterprise's strategic goals constitutes the main purpose of the system (Dorweiler and Yakhou, 2005).

After explaining the relationship between innovation strategies and firm performance, many studies have been conducted in the literature proving the effect of innovation strategies on firm performance (Clifton et al., 2010; Vaccaro et al., 2010; Liao et al., 2010). These studies suggest that firms with innovation strategies would perform better in responding to customers' needs as they can enhance their competitiveness and increase their profitability by developing new capabilities through innovation. The transformation of various combinations through innovation such as new knowledge, idea, technology, and resource provides advantages such as increasing business profitability, reducing costs, and increasing demand (Jimenez and Sanz-Valle 2011; Therrien et al., 2011). However, it is impossible to attain these advantages only through routine activities carried out by the business. Innovation is needed to achieve superiority and make it permanent. Considering the relationship of innovation strategies with firms' production, marketing, and management performance, Zahra et al. (1988) suggested that innovation could continuously positively impact corporate performance. It is possible to reach many studies claiming that customers and suppliers will strengthen the relationship between innovation strategies and performance (Spender, 2007; Terziovski, 2010). These studies emphasize that customers and suppliers make a critical contribution to the relationship of innovation with performance. However, some researchers argue that customer-orientedness will lead to reactive strategies (Baker and Sinkula, 2005). Hurley and Hult (1998) mentioned the positive relationship between organizational innovation and performance.

Similarly, Mazzanti et al. (2006) also mentioned a positive and significant relationship between organizational innovation and performance. Subramanian and Nilakanta (1996) revealed that innovation positively affects the service sector. Thornhill (2006), while emphasizing the effect of the competitive conditions on the relationship between innovation and performance, brought the industry dynamism and company information in the sub-elements of these competitive conditions to the fore.

When the effect of innovation strategies on firm performance is examined, it is understood that the literature mostly focuses on product and process innovations (Bogliacino and Pianta 2011). While product innovation corresponds to the technological competitiveness of the firm, process innovation corresponds to cost competitiveness. Koellinger (2008) found that companies that carry out internet-based innovation activities have higher performance than companies that do not engage in such activities. In addition, innovation activities fed by information management technologies also positively affect company performance (Kostopoulos et al., 2011; Vaccaro et al., 2010). Zahra and Bogner (2000) concluded that technological innovation strategies are positively correlated with return on equity and growth of market share. Irwin et al. (1998) revealed a positive relationship between technological innovation and business 

Companies in Turkey

performance. Damanpour and Evan (1984), applying the management and technological innovation model in their research, concluded that these two types of innovation positively affect business performance.

The literature review shows that innovation strategies positively affect firm performance. The findings obtained from the research results emphasized the general opinion that the business using these strategies is or will be more successful. Thus, the literature review was concluded by reporting empirical findings showing that innovation strategies positively affect firm performance.

Methodology and research methods. The purpose of the current study is to determine the effect of companies' innovation strategies using high technology on their business performance. To this end, the relationship between the dimensions of the scale of innovative strategies such as risk-oriented strategy, proactive strategy, defensive strategy, future-oriented strategy, offensive strategy, and analytical strategy and the dimensions of business performance scale such as product performance, employee-based performance, customer-based performance, financial performance, and process performance will be investigated. Moreover, the innovation and performance levels of the companies using high technology in Turkey were revealed.

Innovation strategies consist of 6 dimensions: Risk-Oriented Strategy, Proactive Strategy, Defensive Strategy, Future-Oriented Strategy, Offensive Strategy, and Analytical Strategy. Business performance was evaluated in 5 dimensions: product performance,employee-based performance, customer-based performance, financial performance, and process performance. Innovation strategies and business performance scales developed by Morgan and Strong (1998), Chandy and Tellis (1998), Eskici (2020) were used. Both scales used in the study are in a five-point Likert scale.

The model of this study, in which the effect of the innovation strategies of the companies using high technology on their business performance is determined, is as follows:

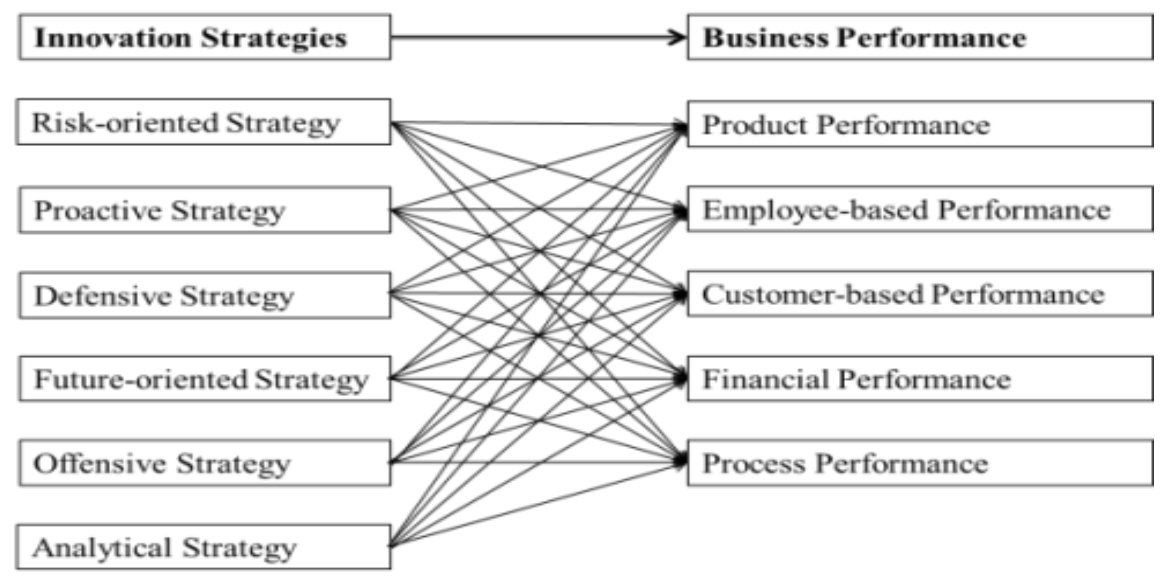

Figure 1. Conceptual model

Sources: developed by the authors.

The hypotheses developed are as follows: $\mathrm{H} 1=$ There is a significant relationship between innovation strategies and business performance (Wu and Lin, 2011; Venkatraman, 1989).

$\mathrm{H} 1 \mathrm{a}=$ There is a significant relationship between offensive strategy and business performance and its dimensions (Miller and Friesen, 1984).

$\mathrm{H} 1 \mathrm{~b}=$ There is a significant relationship between analytical strategy and business performance and its dimensions (Mavondo, 2000; Morgan and Strong, 1998). 
$\mathrm{H} 1 \mathrm{c}=$ There is a significant relationship between defensive strategy and business performance and its dimensions (Kandampully and Duddy, 1999; Kohli and Jaworski, 1990; Chandy and Tellis, 1998).

$\mathrm{H} 1 \mathrm{~d}=$ There is a significant relationship between future-oriented strategy and business performance and its dimensions. (Lyon et al., 2000; Gilbert, 1994; Venkatraman, 1989).

$\mathrm{H} 1 \mathrm{e}=$ There is a significant relationship between proactive strategy and business performance and its dimensions (Ho, 1996; Venkatraman, 1989; Forrester, 2000).

$\mathrm{H} 1 \mathrm{f}=$ There is a significant relationship between risk-oriented strategy and business performance and its dimensions (Brown and Maylor, 2005; Kaplan and Norton, 1996).

A questionnaire was administered to 346 managers of the companies using high technology in Turkey in the study. Due to the strategic importance, the company managers were selected from the energy, telecommunication, chemistry, and computer sectors. The margin of error arising from the sample is $5.18 \%$ at the $95 \%$ confidence level. The questionnaires were administered online between 12 March and 18 July 2021. The collected data were analyzed by using JAMOVI and SPSS 26.0 programs. Exploratory factor analysis, confirmatory factor analysis, Pearson correlation, and regression analysis methods were used in the empirical analysis.

Results. Table 1 demonstrates the demographic information of the companies and managers participating in the study. The majority of the participants are males, and they have education at the undergraduate and graduate levels. In addition, nearly half of the managers have been working in the current business for less than 5 years. In addition, $21.85 \%$ of the participants have $6-10$ years of experience in their related sector. On the other hand, $54.63 \%$ of the companies have $10-49$ employees, and $29.13 \%$ are 26 years old and older.

Table 1. Demographic information about the firms and managers

\begin{tabular}{|c|c|c|c|c|c|c|c|}
\hline & Variables & $\mathrm{n}$ & $\%$ & & $\begin{array}{l}\text { Variables } \\
\text { (Between) }\end{array}$ & $n$ & $\%$ \\
\hline \multirow{2}{*}{ Gender } & Female & 86 & 24.88 & \multirow{5}{*}{$\begin{array}{c}\text { Number of } \\
\text { Employee } \\
\text { s }\end{array}$} & 10 and 49 & 189 & 54.63 \\
\hline & Male & 260 & 75.26 & & 50 and 99 & 36 & 10.32 \\
\hline \multirow{5}{*}{ Age } & $18-29$ & 65 & 18.82 & & 100 and 149 & 36 & 10.32 \\
\hline & $30-39$ & 107 & 30.96 & & 150 and 199 & 36 & 10.32 \\
\hline & $40-44$ & 74 & 21.24 & & 200and more & 50 & 17.57 \\
\hline & $45-49$ & 44 & 12.75 & \multirow{6}{*}{$\begin{array}{l}\text { Firm's } \\
\text { Age }\end{array}$} & $0-5$ years & 36 & 10.32 \\
\hline & 50 and older & 57 & 16.25 & & $6-10$ years & 40 & 11.53 \\
\hline \multirow{6}{*}{$\begin{array}{l}\text { Length of } \\
\text { Service in } \\
\text { the Current } \\
\text { Company }\end{array}$} & $0-5$ years & 168 & 48.55 & & $11-15$ years & 57 & 16.39 \\
\hline & $6-10$ years & 80 & 23.06 & & $16-20$ years & 50 & 14.57 \\
\hline & $11-15$ years & 38 & 10.92 & & $21-25$ years & 63 & 18.21 \\
\hline & $16-20$ years & 23 & 6.68 & & 26 and more & 101 & 29.13 \\
\hline & $21-25$ years & 17 & 4.86 & \multirow{6}{*}{$\begin{array}{l}\text { Length of } \\
\text { Operation } \\
\text { in the } \\
\text { Sector }\end{array}$} & $0-5$ years & 65 & 18.82 \\
\hline & 26 and more & 21 & 6.07 & & $6-10$ years & 76 & 21.85 \\
\hline \multirow{4}{*}{$\begin{array}{l}\text { Education } \\
\text { Level }\end{array}$} & $\begin{array}{l}\text { High school and } \\
\text { lower }\end{array}$ & 50 & 14.57 & & $11-15$ years & 57 & 16.39 \\
\hline & Associate's & 36 & 10.32 & & $16-20$ years & 67 & 19.42 \\
\hline & Undergraduate & 191 & 55.23 & & $21-25$ years & 29 & 8.50 \\
\hline & Graduate & 69 & 20.02 & & 26 and more & 53 & 15.17 \\
\hline
\end{tabular}

Note: Abbreviations: $\mathrm{n}=$ Frequency Distribution. $\%=$ Percentage Distribution.

Sources: developed by the authors.

Next, the exploratory and confirmatory factor analyses and reliability tests conducted on the innovation strategies and business performance scales are presented. 
S., Koyluoglu, M., Dogan. The Impact of Innovation Strategies on Business Performance: Practices in High Technology Companies in Turkey

Table 2. Reliabilities of the innovation strategies scale used in the study

\begin{tabular}{lcccc}
\hline Factors & $\begin{array}{c}\text { Eigenvalue } \\
\text { explained by the } \\
\text { factor }\end{array}$ & $\begin{array}{c}\text { Total variance } \\
\text { explained (\%) }\end{array}$ & $\begin{array}{c}\text { Cronbach Alpha } \\
\text { coefficient }\end{array}$ & $\begin{array}{c}\text { Cronbach Alpha } \\
\text { coefficient for the } \\
\text { whole scale }\end{array}$ \\
\hline $\begin{array}{l}\text { Proactive Strategy } \\
\text { Risk-Oriented }\end{array}$ & 19.751 & & .899 & \\
$\begin{array}{l}\text { Strategy } \\
\text { Defensive }\end{array}$ & 14.422 & & .932 & \\
$\begin{array}{l}\text { Strategy } \\
\text { Future-Oriented }\end{array}$ & 12.224 & 70.231 & .912 & 0.908 \\
Strategy & 10.748 & & .943 & \\
Offensive Strategy & 7.756 & & .921 & \\
Analytical Strategy & 5.330 & & .886 & \\
\hline
\end{tabular}

Sources: developed by the authors.

Table 2 presents the information on the number of factors related to innovation strategies, the total variance explained, and the reliability of internal consistency. The reliability test results showed that all the 6 dimensions of the innovation strategies scale used in the study are «highly reliable» $(>0.80)$. For the whole scale, it was calculated to be 0.908 . Thus, it ensures the reliability of the scale in terms of internal consistency. It can be stated that the explained variance is $70.231 \%$, and this value is high enough for the field of social sciences. Thus, it was concluded that the construct validity of the scale was established.

Table 3. Reliabilities for the business performance scale used in the study

\begin{tabular}{lcccc}
\hline $\begin{array}{c}\text { Factors } \\
\text { (Performance) }\end{array}$ & $\begin{array}{c}\text { Eigenvalue } \\
\text { explained by the } \\
\text { factor }\end{array}$ & $\begin{array}{c}\text { Total variance } \\
\text { explained \% }\end{array}$ & $\begin{array}{c}\text { Cronbach } \\
\text { Alpha } \\
\text { coefficient }\end{array}$ & $\begin{array}{c}\text { Cronbach Alpha } \\
\text { coefficient for the } \\
\text { whole scale }\end{array}$ \\
\hline Financial & 21.009 & & .842 & \\
Customer-Based & 16.528 & 68.001 & .841 & \\
Employee-Based & 12.761 & & .895 & \\
Product & 9.755 & & .921 & \\
Process & 7.948 & & .826 & \\
\hline
\end{tabular}

Sources: developed by the authors.

Table 3 presents information on the number of factors related to business performance, the total variance explained, and the reliability of internal consistency. The reliability test showed that all the 5 dimensions of the business performance scale used in the study are «highly reliable» $(>0.80)$. It was found to be 0.855 for the whole scale. Thus, the reliability of the scale in terms of internal consistency was established. It was concluded that the explained variance is $68.001 \%$.

Since all the items of the innovation strategies and business performance scales have factor loadings higher than 0.50 , all the items remained in the analysis, and no items were discarded. In the CFA, the 6 sub-dimensions and item factor loading values ranged from 0.64 to 0.01 . The standard Goodness-of-Fit Criteria value of the scale of innovation strategies calculated from the model is 183.262; /df value was 1.841 , the CFI value - .911, the GFI value - .897, the SRMR value - .0532, and the RMSEA value - 0609 . The standard Goodness-of-Fit Criteria value of the business performance scale calculated from the model is 192.091 , /df value was 1.756 , CFI value - .919 , GFI value - .878, SRMR value - .0528, and the RMSEA value -0629 . When all the Standard Goodness-of-Fit criteria are evaluated, it is seen that the results of the Confirmatory Factor Analysis are within the limits of acceptable fit. Therefore, the model is significant. 

Companies in Turkey

Table 4 shows the descriptive statistics for the dimensions of the innovation strategies and business performance scales. The dimension of «Proactive Strategy» from the innovation strategies scale and the dimension of «Product performance» from the business performance scale have the highest means. According to Tabachnick and Fidell (2007), the skewness and kurtosis values between +2.0 and -2.0 stated that the scale is normally distributed. Thus, parametric tests should be used. Since the skewness and kurtosis values for the dimensions of the innovation strategies and business performance scales used in the study were found to be between +2.0 and -2.0 , Pearson correlation and multiple regression methods were used.

Table 4. Descriptive statistics for the scales used in the study and their dimensions

\begin{tabular}{cccccc}
\hline Scales & $\mathbf{N}$ & Mean & St. Dev. & Skewness & Kurtosis \\
\hline Offensive Strategy & 346 & 3.08 & 0.65 & -0.22 & 0.40 \\
Analytical Strategy & 346 & 3.92 & 0.75 & -0.83 & 1.42 \\
Defensive Strategy & 346 & 3.74 & 0.58 & -1.10 & 0.95 \\
Future-Oriented Strategy & 346 & 3.77 & 0.73 & -0.85 & 1.46 \\
Proactive Strategy & 346 & 3.80 & 0.84 & -0.51 & 0.11 \\
Risk-Oriented Strategy & 346 & 3.45 & 0.65 & -0.69 & 0.90 \\
Product Performance & 346 & 3.98 & 0.56 & 0.16 & -0.60 \\
Employee-Based Performance & 346 & 3.61 & 0.69 & -0.41 & 0.24 \\
Customer-Based Performance & 346 & 3.67 & 0.57 & -0.64 & 1.28 \\
Financial Performance & 346 & 3.84 & 0.73 & -0.87 & 1.24 \\
Process Performance & 165 & 2.87 & 0.57 & 0.60 & 1.12 \\
\hline
\end{tabular}

Note: Abbreviations: $\mathrm{N}=$ Frequency Distribution. St. Dev.= Standard Deviation.

Sources: developed by the authors.

Pearson correlation and regression analysis revealed the interactions between the innovation strategies and business performance scales and their dimensions.

The relationship between the innovation strategies and business performance was tested with Pearson correlation analysis (Table 5). As a result of the analysis, it was seen that there is no significant correlation between the innovation strategies (offensive, analytical, defensive, proactive, and risk-oriented) and process performance $(p>0.05)$. Similarly, no statistically significant correlation was found between offensive strategy and product, employee-based, customer-based, financial, and process performances $(p>0.05)$. On the other hand, a positive and significant correlation was found between analytical, defensive, future-oriented, proactive strategies and financial performance, customer-based performance, employeebased performance, and product performance $(p<0.05)$. In other words, as the innovation strategies of businesses increased, an increase was determined in the customer-based, employee-based, product, and financial performances.

Table 5. Relationship between the innovation strategies and business performance

\begin{tabular}{lccccc}
\hline & $\begin{array}{c}\text { Product } \\
\text { Performance }\end{array}$ & $\begin{array}{c}\text { Employee-Based } \\
\text { Performance }\end{array}$ & $\begin{array}{c}\text { Customer-Based } \\
\text { Performance }\end{array}$ & $\begin{array}{c}\text { Financial } \\
\text { Performance }\end{array}$ & $\begin{array}{c}\text { Process } \\
\text { Performance }\end{array}$ \\
\hline $\begin{array}{l}\text { Offensive } \\
\text { Strategy }\end{array}$ &.-035 & .102 & .109 & .104 & .034 \\
$\begin{array}{l}\text { Analytical } \\
\text { Strategy }\end{array}$ & $.302^{* *}$ & $.249^{* *}$ & $.674^{* *}$ & $.703^{* *}$ & -.134 \\
$\begin{array}{l}\text { Defensive } \\
\text { Strategy } \\
\text { Future-Oriented }\end{array}$ & $.209^{*}$ & $.229^{* *}$ & $.727^{*}$ & $.684^{* *}$ & -.112 \\
Strategy & $.401^{* *}$ & $.334^{* *}$ & $.691^{* *}$ & $.721^{* *}$ & $.231^{*}$ \\
\hline
\end{tabular}


S., Koyluoglu, M., Dogan. The Impact of Innovation Strategies on Business Performance: Practices in High Technology Companies in Turkey

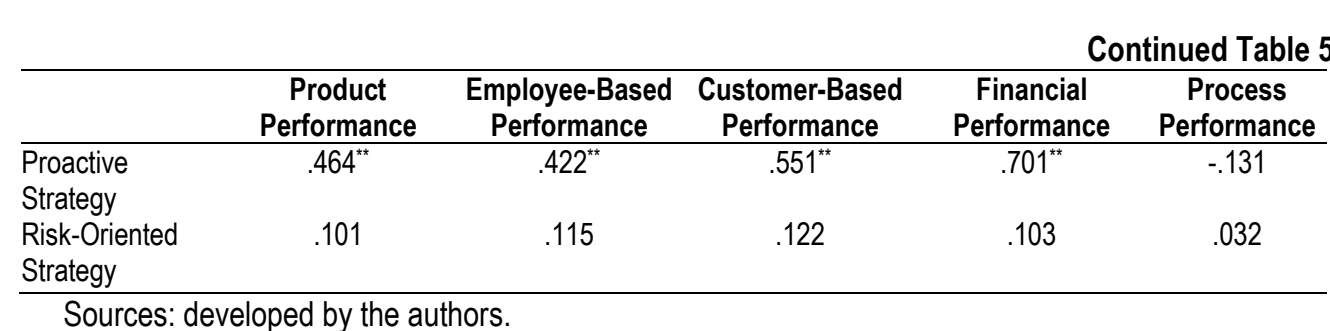

In Table 6, the effect of innovation strategies on business performance is revealed through regression analysis. As a result of the developed model, it is seen that innovation strategies are effective on business performance $(p<0.05)$. Therefore, future-oriented strategy is effective on the product, customer-based, employee-based, financial, and process performances of businesses. As future-oriented strategies of businesses increase, product, customer-based, employee-based, financial, and process performances also increase. On the other hand, future-oriented and risk-oriented strategies do not affect the product, customer-based, employee-based, financial, and process performances of businesses $(p>0.05)$. Similarly, offensive, analytical, defensive, proactive, and risk-oriented strategies do not affect process performance $(p>0.05)$. On the other hand, analytical strategy, defensive strategy, future-oriented strategy, proactive strategy are effective on product performance, customer-based performance, and financial performance of businesses $(p<0.05)$. As a result, innovation strategies most affect customer-based performance $\left(R^{2}=0.687\right)$ and marketing processes' financial performance $\left(R^{2}=0.701\right)$.

Table 6. Effect of innovation strategies on business performance

\begin{tabular}{|c|c|c|c|c|c|c|c|}
\hline \multirow[t]{2}{*}{$\begin{array}{l}\text { Independent } \\
\text { Variables }\end{array}$} & \multirow{2}{*}{$\begin{array}{c}\text { Model } 1 \\
\text { Dependent } \\
\text { Variable: } \\
\text { Product } \\
\text { Performance }\end{array}$} & \multirow{2}{*}{$\begin{array}{c}\text { Model } 2 \\
\text { Dependent } \\
\text { Variable: } \\
\text { Employee- } \\
\text { Based } \\
\text { Performance }\end{array}$} & \multirow{2}{*}{$\begin{array}{c}\text { Model } 3 \\
\text { Dependent } \\
\text { Variable: } \\
\text { Customer- } \\
\text { Based } \\
\text { Performance }\end{array}$} & \multirow{2}{*}{$\begin{array}{l}\text { Model } 4 \\
\text { Dependent } \\
\text { Variable: } \\
\text { Financial } \\
\text { Performance }\end{array}$} & \multirow{2}{*}{$\begin{array}{c}\text { Model } 5 \\
\text { Dependent } \\
\text { Variable: } \\
\text { Process } \\
\text { Performance }\end{array}$} & \multicolumn{2}{|c|}{$\begin{array}{l}\text { Multicollinearity } \\
\text { Statistics }\end{array}$} \\
\hline & & & & & & Tolerance & VIF \\
\hline 1 & 2 & 3 & 4 & 5 & 6 & 7 & 8 \\
\hline (Constant) & $3.352^{* \star}$ & $2.186^{\star \star}$ & $.350^{\star *}$ & $-.181^{*}$ & $3.123^{* *}$ & - & - \\
\hline $\begin{array}{l}\text { Offensive Str. } \\
\text { Analytical Str. }\end{array}$ & $\begin{array}{l}.008 \\
.132^{*}\end{array}$ & $\begin{array}{l}.056 \\
-.071\end{array}$ & $\begin{array}{l}.072 \\
.426^{* *}\end{array}$ & $\begin{array}{l}-.004 \\
.186^{* *}\end{array}$ & $\begin{array}{l}-.011 \\
-.126\end{array}$ & $\begin{array}{l}.798 \\
.804\end{array}$ & $\begin{array}{l}1.213 \\
1.193\end{array}$ \\
\hline Defensive Str. & $.201^{*}$ & -.001 & $.838^{\star *}$ & $.185^{\star *}$ & -.169 & .874 & 1.131 \\
\hline $\begin{array}{l}\text { Future- } \\
\text { Oriented Str. }\end{array}$ & $.205^{*}$ & $.160^{*}$ & $.512^{* *}$ & $.817^{\star *}$ & $.287^{*}$ & .749 & 1.319 \\
\hline Proactive Str. & $.256^{* *}$ & $.340^{*}$ & $.360^{* *}$ & $.507^{* *}$ & -.088 & .902 & 1.098 \\
\hline $\begin{array}{l}\text { Risk-Oriented } \\
\text { Str. }\end{array}$ & -.002 & .001 & .042 & -.011 & .047 & .893 & 1.102 \\
\hline $\begin{array}{l}\text { Significance of } \\
\text { the Model }\end{array}$ & .000 & .000 & .000 & .000 & .000 & & \\
\hline $\mathrm{F}$ & 8.496 & 5.947 & 240.399 & 341.380 & .5021 & & \\
\hline Adjusted $\mathrm{R}^{2}$ & .215 & .153 & .687 & .701 & .072 & & \\
\hline $\begin{array}{l}\text { Durbin- } \\
\text { Watson d }\end{array}$ & 1.896 & 2.041 & 1.981 & 2.176 & 2.291 & & \\
\hline
\end{tabular}
Factor.

Note. Abbreviations: Str.=Strategy. $F=$ Predictor. $\mathrm{R}^{2}=$ Square of the Correlation Value. VIF=Variance Inflation

${ }^{* *}$ means significant at the level of $1 \%,{ }^{*}$ means significant at the level of $5 \%$.

Sources: developed by the authors. 
First-order autocorrelation was tested by using the Durbin-Watson d statistic in the model. The DurbinWatson d statistic usually shows no autocorrelation around 1.5 to 2.5 . The current study calculated the Durbin-Watson d statistic between 1.5 and 2.5. The Variance Inflation Factor (VIF) is used to test the multicollinearity problem and to support the regression model results. In addition, another method used to determine the multicollinearity problem is the tolerance value of the variables. The VIF value below 10 and the tolerance value not very close to 0 mean no multicollinearity problem in the model. In the current study, VIF and tolerance values are quite good. There is no multicollinearity problem and auto-correlation in the model, which shows the robustness and reliability of the model.

Conclusions. For today's businesses, which strive to exist beyond post-modernity, traditional methods are not enough to meet consumers' needs. The faster adaptation to the changing and developing environmental conditions is, the more chance to compete it (Aghion et al., 2005) because, compared to the past, nowadays, the intensity of technology used has increased, and the number of sectors using high technology has increased considerably (Audretsch and Acs, 1991). The applications that were considered as high technology in the 1990s are now accepted as low technology nowadays (Covin et al., 2000). This understanding, which has evolved and placed at the center of competition, has given innovation a strategic identity and created the concept of innovation strategy (O' Regan et al., 2005). Finally, many studies have been carried out on the concept of innovation, which is a guide for businesses. This concept has taken its place in the literature (O'Regan et al., 2005; Lendel and Varmus, 2011). Studies on innovation strategies in the literature have revealed that these strategies positively affect firm performance (Kostopoulos et al., 2011; Vaccaro et al., 2010; Zahra and Bogner, 2000). The findings support the general conviction that businesses with this strategy are more successful (Damanpour and Evan, 1984; Irwin et al., 1998).

The current study examined the effect of innovation strategies of companies using high technology on business performance in terms of marketing processes. The study revealed innovation strategies and product, financial, process, employee, and customer-based performance levels of enterprises using high technology in Turkey. A questionnaire was administered to 346 managers of companies operating in Turkey and using high technology. The collected data were analyzed by using JAMOVI and SPSS 26.0 programs. The findings showed that innovation strategies effectively affect business performance $(p<0.05)$. Among the innovation strategies, the future-oriented strategy was found to be effective on product performance, customer-based performance, employee-based performance, financial performance, and process performance. In other words, as future-oriented strategies of businesses increased, these performances were also found to have increased. On the other hand, it was determined that future-oriented and risk-oriented strategies have no effect on product performance, customer-based performance, employee-based performance, financial performance, and process performance $(p>0.05)$. In addition, the analyses revealed that offensive strategy, analytical strategy, defensive strategy, proactive strategy, and risk-oriented strategy do not affect process performance $(p>0.05)$. On the other hand, it was revealed that analytical strategy, defensive strategy, future-oriented strategy, and proactive strategy effectively affect product performance, customer-based performance, and financial performance of businesses $(p<0.05)$. As a result, innovation strategies had the most impact on two key business performances: 1) customer-based performance $\left(R^{2}=0.687\right)$, which is one of the marketing processes, and $2)$ financial performance $\left(R^{2}=0.701\right)$. This result concurs with the results reported in many studies on this subject in the literature (Spender, 2007; Terziovski, 2010; Karabulut, 2015; Dorweiler and Yakhou, 2005). However, some studies similarly suggested that focusing only on financial processes is not sufficient alone to measure performance, but they approached the subject from different angles (Abdalkrim, 2013).

In the final analysis, the result of the current study showed that innovation strategies of businesses operating in sectors such as energy, telecommunication, chemistry, and computers using high technology are effective on customer-based and financial performance. However, innovation strategies were expected to be effective on other performance indicators in these businesses because as innovation is of 
strategic importance, its effectiveness on other performance levels would mean the efficiency of both these sectors and the enterprises operating in these sectors in Turkey. This situation would increase the production volume by paving the way for new investments in Turkey through the interaction between the sectors. An increase in production volume means an improvement in macroeconomic parameters.

The current study examining the effect of innovation strategies of high-tech businesses on their business performance has some limitations. First of all, as the study had to be conducted during the pandemic, some difficulties were encountered in completing the study, and the process lasted much longer. The difficulties experienced in the data collection are at the forefront of these difficulties. The findings are related to businesses operating in Turkey and using high technology. Increasing the sample size should be considered a limitation, as it might yield different results. Therefore, interpretations should be made in line with these limitations.

In future studies, different dimensions of business strategies could be used because innovation strategies, which are included as sub-strategies in business strategies, have been discussed in different dimensions in the literature (Ansoff and Stewart, 1967; Venkatraman, 1989). In the current study, the strategies proposed by Venkatraman (1989) were used. Including more different dimensions and strategies in future studies would diversify the findings. Increasing the sample size is important for the acceptability of the results. In the current study, high technology sectors were taken as the basis. In future studies, a comparative study with low-tech sectors can be planned. Such a comparison could also be made between different geographical regions and sectors. In addition, an international perspective could be brought to the research by going beyond the borders of Turkey. Finally, different studies could be done by adding mediating variables and the innovation strategies and business performance scales.

Author Contributions: conceptualization, A. S. K. and M. D.; developed theoretical background and literature review, A. S. K.; provided data and prepared methodology, A. S. K. and M. D.; performed the analysis and visualization of results, M. D.; wrote discussion, A. S. K. and was responsible for editing and references control, A. S. K.

Funding: This research received no external funding.

\section{References}

Abdalkrim, G. M. (2013). The Impact of strategic planning activities on private sector organizations performance in Sudan: An empirical research. International Journal of Business and Management, 8(10), 134-143. [Google Scholar]

Afuah, A. (1998). Responding to structural industry changes: A technological evolution perspective. Oxford University Press, 6(1), 183-202. [Google Scholar] [CrossRef]

Aghion, P., Bloom, N., Blundell, R., Griffith, R., \& Howitt, P. (2005). Competition and innovation: An inverted-u relationship. The Quarterly Journal of Economics, 120(2), 701-728. [Google Scholar] [CrossRef]

Akman, G., \& Yılmaz, C. (2008). Innovative capability, innovation strategy and market orientation: An empirical analysis. International Journal of Innovation Management, 12(1), 69-111. [Google Scholar] [CrossRef]

Ansoff, H. I., \& Stewart, J. M. (1967). Strategies for a technology-based business. Harvard Business Review, 45(6), 71-83. [Google Scholar]

Audretsch, Z. J., \& Acs, D. B. (1991). Innovation and size at the firm level. Southern Economic Journal, 57(3), 739-744. [Google Scholar] [CrossRef]

Baker, W. E., \& Sinkula, J. M. (2005). Market orientation and the new product paradox. Journal of Product Innovation Management, 22(6), 483-502. [Google Scholar] [CrossRef]

Bogliacino, F., \& Pianta, M. (2011). Engines of Growth. Innovation and productivity in Industry groups. Structural Change and Economic Dynamics, 22(1), 41-53. [Google Scholar] [CrossRef]

Brown, S., \& Maylor, H. (2005). Strategic resonant firms, mass producers, big fish \& flat liners: A study of policies, practices \& performance in Innovation. Technovation, 25. 307-319. [Google Scholar] [CrossRef]

Cerami, J.R. (2001). Research in organizational design: The capacity for innovation in large, complex organizations. The Innovation Journal, 6(1), 1-17. [Google Scholar]

Chandy, R. K., \& Tellis, G. J. (1998). Organizing for radical product innovation: The overlooked role of willingness to cannibalize. Journal of Marketing Research, 35(4). 474-487. [Google Scholar] [CrossRef 
S., Koyluoglu, M., Dogan. The Impact of Innovation Strategies on Business Performance: Practices in High Technology Companies in Turkey

Clifton, N., Keast, R., Pickernell, D., \& Senior, M. (2010). Network structure, knowledge governance, and firm performance. evidence from innovation networks and smes in the UK. Growth and Change, 41(3), 337-373. [Google Scholar] [CrossRef]

Cooper, R. G. (1984). The performance of product innovation strategies. European Journal of Marketing, 18(5), 5-54. [Google Scholar] [CrossRef]

Cottam, A., Ensor, J., \& Band., C. (2001). A benchmark study of strategic commitment to innovation. European Journal off Innovation Management, 4(2), 88-94. [Google Scholar] [CrossRef]

Covin, J. G., Slevin, D.P., \& Heeley, M.B. (2000). Pioneers and followers: Competitive tactics, environment and firm growth. Journal of Business Venturing, 15, 175-196. [Google Scholar] [CrossRef]

Cozzarin, B. P. (2006). Are world-first innovations conditional on economic performance? Technovation, 26, 1017-1028. [Google Scholar] [CrossRef]

Damanpour, F., \& Evan, W. M. (1984). Organizational innovation and performance: The role of environmental change. Journal of Engineering and Technology Management, 15, 1-24. Retrieved from [Link]

Damanpour, F. (1991). Organizational innovation: A meta analysis of effects of determinants and moderators. Academy Of Management Journal, 34 (3), 555-590. [Google Scholar] [CrossRef]

Dess, G. G., \& Robinson, R. B. (1984). Measuring organizational performance in the absence of objective measures: The case of the privately held firm and conglomerate business unit. Strategic Management Journal, 5(3), 265-273. [Google Scholar] [CrossRef Dorweiler, V. P., \& Yakhou, M. (2005). Scorecard for academic administration performance on the campus. Managerial Auditing Journal, 20 (2), 138-44. [Google Scholar] [CrossRef]

Eskici, R. B. (2020). Impact of innovation strategies on business performance. Master Thesis, Istanbul Trade University, 57-85. Retrieved from [Link]

Forrester, R. H. (2000). Capturing learning and applying knowledge: An investigation of the use of innovation teams in Japanese and American automotive firms. Journal of Business Research, 47, 35-45. [Google Scholar] [CrossRef]

Garengo, P., Biazzo, S., \& Bititci, U. S. (2005). Performance measurement systems in smes: A review for a research agenda. International Journal of Management Review, 7(1), 25-47. [Google Scholar] [CrossRef]

Gilbert, J. T. (1994). Choosing an innovation strategy: Theory and practice. Business Horizons, 337(6), 16. [Link]

Ho, C.H. (1996). A contingency theoretical model of manufacturing strategy. International Journal of Operations \& Production Management, 16(5), 74-98. [Google Scholar] [CrossRef]

Hultink, E. J., \& Robben, H. S. J. (1995). Measuring new product success: The difference that time perspective makes. Journal of Product Innovation Management, 12, 392-405. [Google Scholar] [CrossRef]

Hurley, R. F., \& Hult, G. T. (1998). Innovation, market orientation, and organizational learning: An integration and empirical examination. Journal of Marketing, 62, 42-54. [Google Scholar] [CrossRef]

Irwin, J.G., Hoffman, J. J., \& Lamont, B. T. (1998). The effect of the acquisition of technological innovations on organizational performance: A resource-based view. Journal of Engineering and Technology Management, 15, 25-54. [Google Scholar] [CrossRef Jenssen, J. I., \& Jorgensen, G. (2004). How do corporate champions promote innovations? International Journal of Innovation

Management, 8(1), 63. [Google Scholar] [CrossRef] Jimenez, J. D., \& Sanz-Valle, R. (2011). Innovation, organizational learning and performance. Journal of Business Research, 64(4), 408-417. [Google Scholar] [CrossRef]

Johne, F. A., \& Snelson, P. A. (1988). Success factors in product innovation: A selective review of the literatüre. Journal of Product Innovation Management, 5(2), 114-128. [Google Scholar] [CrossRef]

Kandampully, J., \& Duddy, R. (1999). Competitive advantage through anticipation, innovation and relations. Management Decision, 3(711), 51-56. [Google Scholar] [CrossRef]

Kaplan, R. S. (1998). Innovation action research: Creating new management theory and practice. Journal of Management Accounting Research, 10, 89-118. [Google Scholar]

Kaplan, R. S., \& Norton, D. P. (1996). Using the balanced scorecard as a strategic management system. Harvard Business

Review, 74, 75-85. [Google Scholar] Karabulut, A. T. (2015). Effects of innovation strategy on firm performance: A study conducted on manufacturing firms in Turkey. Procedia-Social and Behavioral Sciences, 195, 1338-1347. [Google Scholar] [CrossRef]

Karlsson, C., \& Olsson, O. (1998). Product innovation in small and large enterprises. Small Business Economics, 10, 32. [Google Scholar] [CrossRef]

Kim, Y., Kim, L., \& Lee, J. (1999). Innovation strategy for local pharmaceutical firms in Korea: A multivariate analysis. Technology Analysis and Strategic Management, 1(1), 29-44. [Google Scholar] [CrossRef]

Koellinger, P. (2008). The Relationship between technology, innovation and firm performance-Empirical evidence from ebusiness in Europe. Research Policy, 37, 1317-1328. [Google Scholar] [CrossRef]

Kohli, A. K., \& Jaworski, B. J. (1990). Market orientation: The construct, research propositions and managerial implications. Journal of Marketing, 54, 1-18. [Google Scholar] [CrossRef]

Kostopoulos, K., Papalexandris, A., Papachroni, M., \& loannou, G. (2011). Absorptive capacity, innovation and financial performance. Journal of Business Research, 64(12), 1335-1343. [Google Scholar] [CrossRef]

Kuczmarski, T. D. (1996). What is innovation? The art of welcoming risk. Journal of Consumer Marketing, 13(5), 7-11. [Google $\underline{\text { Scholar] }}$

Marketing and Management of Innovations, 2021, Issue 4 
S., Koyluoglu, M., Dogan. The Impact of Innovation Strategies on Business Performance: Practices in High Technology Companies in Turkey

Lambkin, M. (1988). Order of entry and performance in new markets. Strategic Management Journal, 9(special issue), 127-140 [Google Scholar] [CrossRef]

Lee-Mortimer, A. (1995). Managing innovation and risk. World Class Design to Manufacture, 2(5), 38-42. [Google Scholar] [CrossRef]

Lendel, V., \& Varmus, M. (2011). Creation and implementation of the innovation strategy in the enterprise. Economics and Management, 16, 819-826. [Google Scholar]

Li, Q., Maggitti, P. G., Smith, K. G., Tesluk, P. E., \& Katila, R. (2013). Top management attention to innovation: The role of search selection and intensity in new product introductions. Academy of Management Journal, 56(3), 893-916. [Google Scholar] [CrossRef]

Liao, C. C., Wang, H. Y., Chuang, S.H., Shih, M.L., \& Liu, C.C. (2010). Enhancing knowledge management for R\&D innovation and firm performance: An integrative view. African Journal of Business Management, 4(14), 3026-3038. [Google Scholar] [CrossRef

Liao, T. S., \& Rice, J. (2010). Innovation investments, market engagement and financial performance: A study among australian manufacturing SMEs. Research Policy, 39, 117-125. [Google Scholar] [CrossRef]

Lynn, G. S., \& Mazzuca, M. (1998). Learning the critical success factor in developing truly new products. Research Technology Management, 41(3), 45-53. [Google Scholar] [CrossRef]

Lyon, D. W., Lumpkin, G. T., \& Dess, G. G. (2000). Enhancing entrepreneurial orientation research operationalizing and measuring a key strategic decision making process. Journal of Management, 6(5), 1055-1085. [Google Scholar] [CrossRef]

Maggitti, P. G., Smith, K. G., \& Katila, R. (2013). The complex search process of invention. Research Policy, 42, 90 -100. [Google Scholar] [CrossRef

Manu, F. A., \& Sriram,V. (1996). Innovation, marketing strategy, environment and performance. Journal of Business Research, 35, 79-91. [Google Scholar] [CrossRef]

Mavondo, F. T. (2000). Marketing as a form of adoption: Empirical evidence from a developing economy. Marketing Intelligence \& Planning, 18(5), 256-272. [Google Scholar] [CrossRef]

Mazzanti, M., Pini P., \& Tortia, E. (2006). Organizational innovations, human resources and firm performance: The EmiliaRomagna food sector. The Journal of Socio-Economics, 35,123-141. [Google Scholar] [CrossRef]

Meeus, M. T. H., \& Oerlemans, L. A. G. (2000). Firm behavior and innovative performance: An empirical exploration of the selection-adoption debate. Research Policy, 29, 41-58. [Google Scholar] [CrossRef

Miller, D., Friesen, P. H., \& Mintzberg, H. (1984). Organizations: A quantum view. Prentice Hall. [Google Scholar]

Morgan, R. E., \& Strong, C. A. (1998). Market Orientation and Dimensions of Strategic Orientation. European Journal of Marketing, 32(11-12), 1051-1073. [Google Scholar] [CrossRef]

O'Regan, N., Ghobadian, A., \& Gallear, G. (2005). In search of the drivers of high growth in manufacturing SMEs. Technovation, 26(1), 30-41. [Google Scholar] [CrossRef]

Oke, A., Walumbwa, F. O., \& Myers, A. (2012). Innovation strategy, human resource policy, and firms' revenue growth: The roles of environmental uncertainty and innovation performance. Decision Sciences, 43(2), 273-302. [Google Scholar] [CrossRef]

Osman, S., Shariff, S. H., \& Laijn, M. N. A. (2016). Does innovation contribute to employee performance. Procedia - Social and Behavioral Sciences, 219, $571-579$. [Google Scholar] [CrossRef]

Pichler, J. (2010). Innovation and creative destruction: At the centennial of schumpeter's theory and its dialectics. Review Papers, 56, 5-6. [Google Scholar]

Prajogo, D. I., \& Sohal, A. S. (2001). TQM and innovation: A literature review and research framework. Technovation, 21, 539-

558. [Google Scholar] [CrossRef]

Souissi, M., \& Itoh, K. (2006). Implementing the balanced scorecard. The Journal Of Corporate Accounting \& Finance, 17(3) 57-61. [Google Scholar] [CrossRef]

Spender, J. C. (2007). Data, meaning and practice: How the knowledge-based view can clarify technology's relationship with organizations. International Journal of Technology Management, 38(1-2), 178-96. [Google Scholar]

Steele, J., \& Murray M. (2004). Creating, supporting and sustaining a culture of innovation engineering. Construction and Architectural Management, 11(5), 316-322. [Google Scholar] [CrossRef]

Subramaian, A., \& Nilakanta, S. (1996). Organization innovative: Exploring the relationship between organization determinants of innovation, types of innovations, and measures of organizational performance Omega. International Journal of Management Science, 24(6), 631-647. Retrieved from [Link]

Tabachnick, B. G., \& Fidell, L. S. (2007). Using Multivariate Statistics. Massachusetts: Allyn \& Bacon. [Google Scholar]

Terziovski, M. (2010). Innovation Practice and its performance implications in small and medium enterprises (SMEs) in the manufacturing sector: A resource-based view. Strategic Management Journal, 31, 892-902. [Google Scholar] [CrossRef]

Therrien, P., Doloreux, D., \& Chamberlain, T. (2011). Innovation novelty and (Commercial) performance in the service sector: A Canadian firm-level analysis. Technovation 31(12), 655-665. [Google Scholar] [CrossRef]

Thornhill, S. (2006). Knowledge, innovation and firm performance in high- and low-technology regimes. Journal of Business Venturing, 21, 687-703. [Google Scholar] [CrossRef]

Tomlinson, P.R. (2010). Co-operative ties and innovation: Some new evidence for UK manufacturing. Research Policy, 39, 762-775. [Google Scholar] [CrossRef] 
S., Koyluoglu, M., Dogan. The Impact of Innovation Strategies on Business Performance: Practices in High Technology Companies in Turkey

Vaccaro, A., Parente, R., \& Veloso, F. M. (2010). Knowledge management tools, interorganizational relationships, innovation and firm performance. Technological Forecasting and Social Change, 77(7), 1076-1089. [Google Scholar] [CrossRef]

Veliu, L., \& Manxhari, M. (2017). The impact of managerial competencies on business performance: SME's in Kosovo. Journal of Management, (1), 30. [Google Scholar]

Venkatraman, N. (1989). Strategic orientation of business enterprises: The construct, dimensionality, and measurement. Management Science, 35(8), 942-962. [Google Scholar] [CrossRef]

Venkatraman, N., \& Ramanujam, V. (1986). Measures of business performance in strategy research: A comparision of approaches. Academy of Management Review, 11(4), 801-814. [Google Scholar] [CrossRef]

Veugelers, R., \& Cassiman, B. (1999). Make and buy in innovation strategies: Evidence from belgian manufacturing firms. Research Policy, 28, 63-80. [Google Scholar] [CrossRef]

Wright, P., Kroll, M., Pringle, C., \& Johnson, J. (1990). Organizational types, conduct, profitability and risk in the semiconductor industry. Journal of Management Systems, 2(2), 33-48. [Google Scholar]

Wu, S. I., \& Lin, C. L. (2011). The influence of innovation strategy and organizational innovation on innovation quality and performance. International Journal of Organizational Innovation, 3(4), 45-81. [Google Scholar]

Zahra, S. A., \& Bogner, W. C. (2000). Technology strategy and software new venture's performance: Exploring the moderation affect of the competitive environment. Journal of Business Venturing, 15(2), 123-173. [Google Scholar] [CrossRef]

Zahra, S. A., Belardino, S., \& Boxx, W. R. (1988). Organizational innovation: Its correlates and its implications for financial performance. International Journal of Management, 6, 133-142. [Google Scholar]

Zhuang, L. (1995). Bridging The gap between technology and business strategy: A pilot study on the innovation process. Management Decision, 33(8), 13-21. [Google Scholar] [CrossRef]

Сельчук Койлуоглу, Сельджукський університет, Туреччина

Месут Доган, Університет Афйон Коджатепе, Туреччина

Інноваційні стратегії розвитку високотехнологічних компаній Туречиини

Впровадження інновацій спрямовано на досягнення конкурентних переваг шляхом покращення критеріїв ефективності, що сприяє формуванню міцних зв'язків між інноваціями та продуктивністю. Метою статті є визначення впливу інноваційних стратегій на ефективність діяльності високотехнологічних підприємств. У роботі, запропоновано класифікаційні ознаки та виділено шість типів інноваційних стратегій: 1) проактивна стратегія, 2) ризикоорієнтована стратегія, 3) оборонна стратегія, 4) стратегія на майбутнє, 5) стратегія наступу та 6) аналітична стратегія. Оцінювання ефективності ведення бізнес-діяльності здійснено за пятьма напрямами: якість продукції, продуктивність праці, взаємодію зі споживачами, результати фінансової діяльності та ефективність процесів, за шкалою Морган та Стронг (1998), Ченді та Теліс (1998), а також Ескічі (2020). Підґрунтям дослідження стали результати опитування 346 менеджерів високотехнологічних компаній Туреччини. Аналіз результатів опитування було здійснено за допомогою програмного забезпечення JAMOVI та SPSS 26.0. Емпіричне дослідження проведено з використанням інструментарію експлораторного та конфірматорного факторних аналізів, коефіцієнта кореляції Пірсона та регресійного аналізу. За результатами дослідження встановлено, що інноваційні стратегії сприяють підвищенню ефективності діяльності високотехнологічних підприємств. Зокрема, стратегія на майбутнє сприяє покращенню якості продукції, продуктивності праці, взаємодії зі споживачами, фінансовій результативності та ефективності процесів. Однак, результати дослідження засвідчили, що стратегія на майбутнє та ризикоорієнтована стратегія $\epsilon$ неефективними для показників якості продукції, взаємодії зі споживачами, продуктивності праці, результатів фінансової діяльності та ефеективності процесів. Наступальні, аналітичні, оборонні, проактивні та ризикоорієнтовані стратегії не $\epsilon$ еффективними для підвищення продуктивності процесів. Аналітичні, оборонні, орієнтовані на майбутнє та проактивні стратегії ефективні для якості продукції, взаємодії зі споживачами та фінансової результативності. На основі отриманих результатів дослідження автори дійшли висновку, що інноваційні стратегії мають сильніший вплив на ефективність взаємодії зі споживачами $(\mathrm{R} 2=0,687)$ та фінансову результативність $(\mathrm{R} 2=0,701)$ високотехнологічних компаній.

Ключові слова: інновація, інноваційні стратегії, ефективність бізнес-діяльності, високі технології. 